\title{
Polysèmes
}

Revue d'études intertextuelles et intermédiales

\section{Jocelyn Brooke's The Military Orchid: A Literary Hybrid}

Catherine Hoffmann

\section{OpenEdition}

Journals

Édition électronique

URL : http://journals.openedition.org/polysemes/2531

DOI : $10.4000 /$ polysemes. 2531

ISSN : 2496-4212

Éditeur

SAIT

Référence électronique

Catherine Hoffmann, « Jocelyn Brooke's The Military Orchid: A Literary Hybrid », Polysèmes [En ligne], 19 | 2018, mis en ligne le 30 juin 2018, consulté le 20 avril 2019. URL : http://journals.openedition.org/ polysemes/2531; DOI : 10.4000/polysemes.2531

Ce document a été généré automatiquement le 20 avril 2019.

Polysèmes 


\title{
Jocelyn Brooke's The Military Orchid: A Literary Hybrid
}

\author{
Catherine Hoffmann
}

\section{NOTE DE L'AUTEUR}

I wish to thank Jonathan Hunt, formerly of the Open University co-publishing

Department, and Linda Ho Peche, intern at the Harry Ransom Humanities Research

Center, University of Texas at Austin, for their kind and valuable assistance.

1 The Military Orchid, autobiographical in form and partly so in content, appeared in 1948. It was Jocelyn Brooke's first published novel and was followed in close succession by A Mine of Serpents (1949) and The Goose Cathedral (1950), all three based on the same narrative principles and forming a fictionalised autobiographical trilogy. ${ }^{1}$ The title is not, as may be assumed by readers unfamiliar with botany, a metaphor, but the name of a very rare species of orchid, though metaphorical meanings can be read into it, encouraged by the botanists' taste for anthropomorphic names. The genesis of the work accounts for both the title and the hybrid nature of the narrative. Until then, Brooke's novelistic attempts had failed: two post-war novels were rejected, and he had given up his earlier hope of writing his own Proustian masterpiece. After the war he resumed work on a botanical monograph, The Wild Orchids of Britain. His agent also suggested, at the same period, that he write a popular book about flowers. This eventually became The Military Orchid, not quite the work initially intended. Its form and contents may be regarded partly as the result of earlier novelistic failure, partly as the direct offshoot of Brooke's botanical studies. Though The Wild Orchids of Britain was published in 1950, after The Military Orchid, work on it had started long before and was, presumably, still going on while the novel was in progress.

2 My purpose is to examine some of the generic questions raised by the interaction of context, text, and intertext in The Military Orchid. Context, in relation to Brooke's novel, refers to the autobiographical material as well as to the botanical external reality from 
which much of the text proceeds. The many works mentioned, quoted, or alluded to, whether of a botanical or literary kind, subsume context into text through extensive intertextual practice: while they belong to the real, referential world of Brooke's life, they also contribute to the production of the peculiar breed of narrative that is The Military Orchid. It should further be noted that the botanical works used by the protagonist contain illustrations, plates representing different species of orchids, as does Brooke's monograph, or, as he preferred to label it, iconograph, The Wild Orchids of Britain, illustrated with watercolours by the artists Gavin, Muirhead, and Stephen Bone. While there are no such plates in The Military Orchid, the narrator refers to the illustrations of floras that he possessed. Besides, his own verbal "sketches" of orchids may be said to play an analogous role, though they are not, like the plates, extra- and non-textual, but part of the narrative discourse.

Much critical and theoretical interest has been generated, over the past decades, by generic borderline cases in literature and the present study of Brooke's autobiographical novel has been to some extent conducted in the light of, though not always in full agreement with, Dorrit Cohn's The Distinction of Fiction, in particular the chapter in which she suggests that referential narratives, as opposed to fictional ones, should be studied by narratologists on the basis of a three-level model-reference/story/discourse-instead of the traditional two-level model story/discourse. ${ }^{2}$ My basic theoretical contention is that, in some cases, the three-level model may also yield profitable results when applied to narratives which Dorrit Cohn would exclude from the referential category, her argument being that generic borderline cases, "far from effacing the border they straddle, offer an opportunity to study the historical and theoretical grounds for its existence" (116). ${ }^{3}$

\section{À la recherche de l'orchidée perdue: The Military Orchid as quest novel and Bildungsroman}

In this part, I intend to examine those characteristics of the narrative which encourage a reading of The Military Orchid as fiction. I should also mention that some elements of the peritext prescribe this kind of reading: the publisher's generic labelling on the book cover, The Military Orchid and Other Novels and the author's note:

This book is not, strictly, an autobiography, and the author has taken a novelist's liberties both with persons and institutions. I hope that 'St Ethelbert's' and schools of its kind have long ceased to exist; as for the dramatis personae, so far as they impinge upon reality at all, they are to be considered as caricatures rather than characters.

The reader may, however, remain impervious to these signs of fictional intentionality, and I think that our reading of The Military Orchid as a novel is conditioned mostly by the narrative method used. The opening of the narrative is, in this respect, revealing: while the "I" is momentarily relegated to the background, pride of place is given to Mr Bundock, whose claim to narrative prominence lies in his discovery of a Lizard Orchid, the name of the plant placed strategically at the end of the first paragraph and introducing the orchid theme:

Mr Bundock's function, so far as my family was concerned, was to empty the earthcloset twice a week at the cottage where we used to spend the summer. This duty he performed unobtrusively and usually late at night: looming up suddenly in the summer-dusk, earth-smelling and hairy like some menial satyr, a kind of Lob. (Perhaps the maids left a bowl of cream for him on the threshold.) He became of 
sudden interest to me one June evening by asserting, quite calmly, that he had found the Lizard Orchid. (19) of mediator between the orchids and the child protagonist-a function he shares with other characters who appear later. It is through his producing another, mysterious, orchid, that the moral theme of the novel and the object of the quest are defined: the seven year old "I" character is at first tempted to identify the unknown specimen as Orchis militaris, rare and highly desirable in his eyes:

according to Colonel Mackenzie, the plant was none other than Orchis militaris, the Military Orchid. But according to Edward Step, it might equally well-more probably, in fact-the Orchis purpurea, the Great Brown-Winged Orchid, which the Colonel didn't even so much as mention. The discrepancy provoked in me a moral conflict; for I wanted, very badly, to find Orchis militaris. (21) different species. The moral theme of the novel thus translates honesty into precise naming and strict distinction between categories. The protagonist's scientific honesty also constitutes a necessary condition of the quest itself: it is his awareness of the elusiveness of the Military Orchid which makes the plant so desirable and thus guarantees that his search will go on. In fact, the narrator reveals very early that he has never reached his objective, a departure from more traditional quest narratives where the reader's ignorance of the outcome parallels the hero's. ${ }^{4}$

7 In keeping with the theme and pattern introduced in the first chapter, the material is mostly selected in function of its relevance to the quest, so that the choice of periods, places, characters and anecdotes is subordinate to the protagonist's botanical interests and to his search for the military orchid. Physically, the text is divided into three parts, each corresponding roughly to a stage and a place in the narrator's life: I, A Box of Wormseed is mostly set in Kent and covers periods of his childhood; II, Du Côté de chez Prufrock, deals with his adolescence at school; III, The High Mountains of Clova with his war service in Italy.

The thematic coherence achieved through the selection of material and the highlighting of patterns is reinforced by the use of a refrain-"The Military Orchid was still unfound" $(22,51)$ and its variant "the Military Orchid had eluded me once again" $(79,80)$-which, together with the repetition of the orchid's name throughout the text, provides a sort of internal rhythmic beat and contributes to the coherence of texture.

9 Though the temporal treatment is roughly chronological, whole periods are missingsome of them dealt with in the other novels of the trilogy. Besides, the detail of the text reveals many anachronies at the level of sentences or paragraphs, with references to different periods of the protagonist's life and to the narrator's present. These obviously reflect the process of reminiscence but also serve to emphasise continuity and evolution in his botanical and intellectual attitudes.

10 Indeed, The Military Orchid may also be read as a kind of Bildungsroman which charts the protagonist's development in two areas: botany and literature. This narrowing of the narrator's perspective on his own earlier self further elicits a reading of the narrative as fiction, which an insistence on formative years and education would not in itself justify, being a feature shared by biography/autobiography and the Bildungsroman.

11 As far as botany is concerned, the persistence of the protagonist/narrator in his quest for the Military Orchid bridges the temporal gap between his childhood and his present as 
narrator. However, the narrative also charts the evolution of his botanical activities, from observing specimens found by others to discovering them himself, the steps of his botanical education and the different phases of his attitude to his hobby. Besides, the narrative registers the various emotional states induced by his botanical adventures, and signals transition from one stage of life to another through 'orchid' episodes which echo each other:

One morning [...] a small parcel arrived for me. I undid it, and with difficulty choked down my tears. It contained orchids found by my old Nurse near the cottage, whither the family had already repaired for the summer. Not for yearsnot till I had left school-should I ever be able to find these orchids myself again [...]. I realized it for the first time that morning; and the yellowish spikes of the Man, the purple-spotted pagodas of the Lady, awoke in me a nostalgia which was no ordinary homesickness, but a sense of greater loss. I realized, at last, that my childhood was nearly over. (50)

To myself, the assembled orchids [for the school Show], in their jam-pots and potted-meat jars, were so many symbols of a happiness which was so acute, so consciously enjoyed, that it filled me with a kind of superstitious fear. To be so happy at school seemed to me against nature; I could only marvel, as the exciting, sunlit weeks slipped by, that I had actually forgotten to look forward to the holidays. [...] I had become, in fact, a different person. (63)

Concerning the protagonist's literary formation and development, the narrative provides a humorous account of early attempts at novel writing and the narrator cheerfully derides his youthful prolific production: its confusion between author and character, its intellectual pretensions and inability to rid itself of the influence of the Huxley of Crome Yellow and Antic Hay:

Shepherd's Hey was nothing more or less than a Huxleyfied version of my daily life at school; my friends were portrayed without the least disguise; whole conversations went down almost verbatim. True, some of the characters-particularly myselftended to speak the Huxley dialect: but after all, I was trying hard to speak it in real life. I wrote chapter after chapter with immense enjoyment: there seemed no reason why the book should ever come to an end. [...] While I wrote it, I identified myself so completely with the hero that I find it almost impossible to remember, nowadays, whether certain episodes really happened, or whether I invented them.

(72)

Later, on the eve on the Second World War, the protagonist consigns some of these juvenile efforts to the funeral pyre. The narrative, however, remains silent about later stages in his literary learning process. In this respect the Bildungsroman is incomplete, stopping as it does at the point when the mature "I" rejects his adolescent works. What the narrative does, though, is to set firmly the protagonist's literary make up within the intellectual atmosphere of the 1920s. Through quotations, the sources of which are sometimes identified but mostly not, and references to various works and their authors, the " $\mathrm{I}$ " character is presented, like the orchid specimens in their natural environment, in his "intellectual" habitat, a reader of Arnold's Scholar Gypsy and Thyrsis, of Housman's poetry, followed by Eliot's The Love Song of J. Alfred Prufrock, Huxley, and, as may be expected, Firbank and Proust, those most orchidaceous of writers. ${ }^{5}$ The list itself is neither extensive nor original but the high incidence of quotations, particularly when they are not integrated into the narrator's discourse but typographically demarcated from it, visibly affects the texture of the work and our reading of it, since in their own way they draw attention to its hybridism and composite nature. 


\section{"Almost, but not quite": the signs and forms of hybridism}

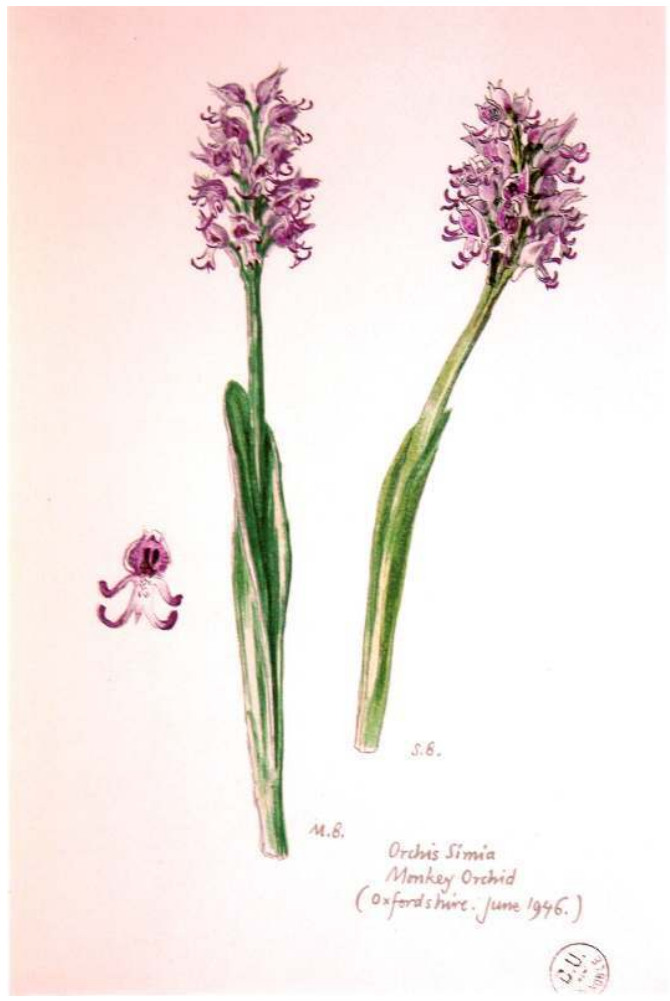

Orchis Simia (Monkey Orchid, Oxfordshire: June 1946), The Wild Orchids of Britain, plate 27

"Almost, but not quite" is the last sentence of the novel. Elliptical and logically redundant, it applies to a specimen of Orchis simia found by the protagonist in Italy, "almost worthy to be called Orchis militaris" (107). The final sentence expresses, in concentrated form, the moral configuration of the quest, and the unbridgeable gap, however narrow, between desires and temptation on the one hand ("almost", and its hopeful connotation), and acceptance of disappointing facts on the other ("not quite", and its negation of hope, which simultaneously reveals a moral victory). The difference, for the narrator, is one of perspective.

From a reader's point of view, The Military Orchid can be regarded as almost a novel but not quite, almost an autobiographical essay but not quite, a hybrid belonging to this class of generically ambiguous narratives which, according to Philippe Gasparini "programment une double réception, à la fois fictionnelle et autobiographique quelle que soit la proportion de l'une et de l'autre". ${ }^{6}$ Dorrit Cohn does not, for her part, envisage this kind of reception, though she shares Gasparini's belief that our reading does not depend on the degree of fictionality or referentiality. Where her position radically diverges from Gasparini's is in her assertion that we read those borderline texts "in one key or the other" (35), a position which the first part of my study vindicates. Such generically ambiguous texts are not infrequent in literature, and we know that La Recherche, a case in point, was a major influence on Brooke:

Proust seemed a kind of extended and glorified version of myself. Reading Swann, I can remember saying to myself: "But this is me". À la Recherche du Temps Perdu was, I 
decided, not only the novel-to-end-all-novels, but more especially, my novel-a book which might have been written for myself alone, and which, as I read on, seemed miraculously to enlarge and amplify my own personality. For the next few years, I was almost exclusively absorbed in it. ${ }^{7}$

and of the treatment of self and selfhood. The name of the protagonist/narrator is mentioned only once in The Military Orchid about half-way through, in the form of gossip in free indirect discourse: "Later, when I left the Library, there were titters: Brooke had been passing notes to Dorothy" (65). Identity with the real author's surname could be taken to signal autobiographical intentions. Yet, this single occurrence, in passing, may escape the reader's notice and does not substantially alter our reception of the text as fiction.

17 I have already mentioned the subordinate position of the first person in the opening paragraph of the novel, but have said nothing of the epigraph from which the title of the first part, A box of wormseed, derives: "Thou art a box of wormseed, at best but a salvatory of green mummy" comes from Webster's The Duchess of Malfi, and is Bosola's answer to the Duchess's question "Who am I?". Whereas the Duchess's question is intended to test Bosola rather than as expression of ontological uncertainty, the spy's answer reduces the Duchess's proud self to low-grade vegetable form and decomposing matter.8 If we leave aside the medicinal and recycling virtues of wormseed and green mummy, Bosola's answer certainly suggests a complete dissolution of the self, body and soul. How far this may apply to the narrator's own vision of himself as character is open to conjecture, but, as an entrée-en-matière for an autobiographical narrative, it deflates the notion of self rather radically and keeps its grammatical incarnation out of the reader's sight by quoting the "thou" of the answer but not the "I" of the question. In the narrative itself, the narrator often depreciates himself, admitting shortcomings, failure, mania, amateurism. The sense of defeatism is however more pronounced in the other two novels of the trilogy, whereas in The Military Orchid, botany, despite the failure of the quest, remains a source of great happiness as well as the centre of the self's moral life. ${ }^{9}$ After all, on the axiology of botanical accuracy and honesty established within and by the text, the protagonist/narrator shares the upper reaches with the best authorities. Botany thus appears as the means by which both self and narrative are held together: it prevents the transformation of the self into mere wormseed by solidifying it in the configuration of the quest narrative, and its related theme of resistance to false gratification of desire through self-delusion.

18 "This book", the narrator warns the reader in an aside, "is largely about flowers" (24). of course, we need not automatically take his pronouncements at face value, yet, in the case of The Military Orchid, the reader too is likely to conclude that, yes indeed, this book is largely about flowers. In applying Dorrit Cohn's three level model to The Military Orchid, I wish to consider the referential level of botany in relation both to the diegetic universe, and to the text (the narrative discourse) and some aspects of its peritext.

19 Human characters, said by the author to be caricatures and not real people, mostly play a secondary and temporary role generally subordinate to the orchid quest. There is no 
difficulty therefore in perceiving them as the imaginary creatures who people the diegetic world. By contrast, the orchids in the cast of botanical "characters" exist in the external, real world, their existence attested in serious botanical works and their plates. That they are also an essential component in the construction of the narrator's own mythical universe does not alter the fact that much of the story material, the quest and its sequence, depend on three botanical facts:

-firstly, the rarity of the Military Orchid and the Monkey Orchid (Orchis simia) in

Britain and elsewhere in Europe;

-secondly, the close resemblance between them, and a third related kind, the Lady Orchid (Orchis purpurea);

-finally and consequently, the tendency or decision, on the part of some botanists (the debate is an on-going one it seems), to consider them as subspecies of a single species.

Though other orchids and plants are referred to in the text, the Military, the Monkey and the Lady Orchids constitute the main botanical "characters". As suggested earlier on, this role is helped by their anthropomorphic names and by the protagonist/narrator's strong emotional investment in them, although they are not actually personified and we are aware that they exist, in their own right, outside the diegetic universe created by the narrative.

This impression results from the dialogic interweaving of botanical discourse and narrative discourse. The following passage, set in the mess of a military hospital in North Africa, to which the protagonist is posted, offers a typical example:

On one of the tables stood a bowl full of tall pinkish flowers. I went to look at them: I looked again; at last I took one out of the bowl. Yes, there could be no doubt: the plant I held in my hand was the Military Orchid.

At that moment a woman emerged from the kitchen-quarters. [...] [s] he was Italian, but spoke a little French. [...] I asked her about the Orchid: did she know where it grew? She didn't. Who had found it? M. le Colonel had found it. Was M. le Colonel in the mess, I inquired? At that moment I, a private, would have been quite prepared to beard the Colonel in his bedroom, or even in the lavatory, had he been there. [...] I asked if I might take a specimen. Mais volontiers, she replied. [...]

Owing [...] to the exigencies of military etiquette, the Military Orchid had eluded me once again. I consoled myself, however, on a closer examination of the plant, by deciding that it was not, after all, the true Military. The divisions of the mid-lobe were too narrow: it was probably an "intermediate" between Orchis militaris and Orchis simia. (When I returned to England the plant was identified as a variety tridentata of Orchis militaris.) (79-80)

In this passage, as in many others, the use of the Latin names of the plants underlines the shift from narrative discourse to botanical discourse and, more generally, the Latin names, also used in the passages of narratorial commentary, contribute to the text's heteroglossia, immediately visible on the many pages where the standard printed text is interspersed not only with botanical Latin names but also bits of Italian and French, all in italics.

In the absence of illustrations, which would have accentuated the referential, botanical nature of the text to the point of jeopardising its fictional character, the evocation of the orchids depends on the narrator's descriptions. These are sometimes set against descriptions provided by existing botanical works, and restricted to observation of the shape and colours of the different parts of the flowers. ${ }^{10}$ In other cases, however, the descriptions convey the protagonist's admiration for the remarkable specimens he finds, and form a textual equivalent of an artist's impression of orchids, comparable in spirit 
with the plates of Wild Orchids of Britain. ${ }^{11}$ Here, for instance, is the narrator's evocation of the first Lady Orchid he found as a child:

it was the Brown-Winged-or, as it is more pleasantly called, the Lady Orchid; the most regal of British orchids, and perhaps the loveliest of English wildflowers: its tall pagodas of brown-hooded, white-lipped blossoms towering grandly, like some alien visitor, exotic as Miss Trumpett at a village tea-party, above the fading bluebells and the drab thickets of dog's mercury, in a wood which I had known all my childhood, but whose distinguished inhabitant I had never before discovered. (30)

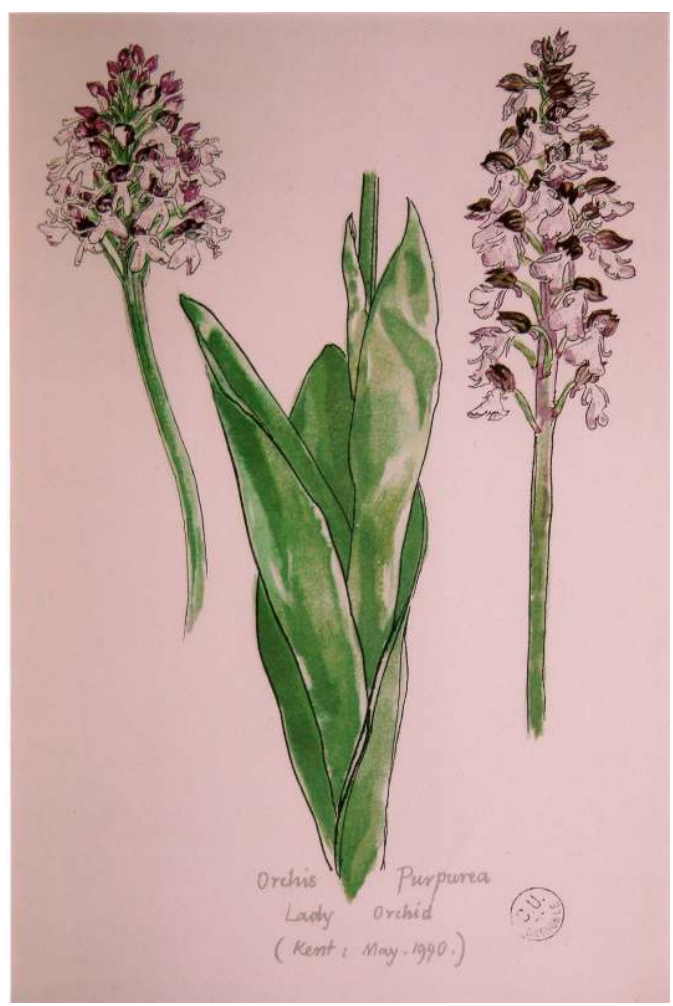

Orchis Purpurea (The Lady Orchid, Kent: May 1940), The Wild Orchids of Britain, plate 28 text where the analogies are reversed and people are seen as botanical specimens. Thus, the exotic Miss Trumpett of the quotation is later characterised as "orchidaceous" (42) while other neighbours are assessed in botanical terms too, metaphors and comparisons which reflect the narrator's attraction towards hybrid forms of life.

Another way in which botany informs narrative discourse is through what can be termed "botanical intertextuality". This includes bibliographical references given either in the text, or in the peritext as part of the epigraphs, all from botanical works and all concerning the Military Orchid, or in a footnote (there are three narratorial footnotes in The Military Orchid, the first one, on page 20, providing bibliographical information about Godfery's monograph on British Orchids). In addition, the text contains many quotations from these works, works which appear also in the bibliography of The Wild Orchids of Britain (8 of the 23 works listed in the monograph are mentioned and/or quoted in the novel). In The Military Orchid, as in referential narratives, the "extratextual documentary base [...] penetrates into the textual terrain itself which as Michel de Certeau puts it "combines the plural of quoted documents into the singular of quoting cognition"' (Cohn 115). ${ }^{12}$ The narrator adopts a critical attitude to those bibliographical references 
and devotes whole passages to assessing the scientific accuracy of the works, the quality of their plates-generally regarded as poor artistically and misleading-and, in one case, to rescuing forgotten Victorian floras from unjustified oblivion.

Finally, a comparative reading of The Military Orchid and The Wild Orchids of Britain reveals the process of cross-fertilisation at work here: similar scientific data, anecdotes about the author's or narrator's finds, shared lyricism in praising the beauty of wild orchids, sense of place, stressed in both works, use of the same literary quotations, as can be observed in the two following passages, both dealing with Orchis mascula. The first extract is from the monograph:

[this popular name] suggests that Orchis mascula is the 'long purples' of Shakespeare That liberal shepherds give a grosser name But our cold maids do dead-men's-fingers call them.

Shakespearian scholars, however, seem strangely unable to agree on this point. According to some authorities, the plant in question is the Cuckoopint or Lordsand-ladies. Others favour the Purple Loosestrife-a view apparently supported by Millais' famous picture-though here is nothing about the Loosestrife which could tempt anybody, however liberal, to bawdy comparisons, whereas the tubers of Orchis mascula have earned for it a number of "grosser names" [...] (Even the Latin specific name refers to the testicular form of these tubers-a feature which, however, is by no means peculiar to the Early Purple.) (88)

This second extract is from the novel:

Shakespeare seems to have had a genuine taste for flowers, [...]-and wild ones at that; more over, he is often unusually explicit-though sometimes his nomenclature has given rise to confusion, as with the long purples,

That liberal shepherds give a grosser name, But our cold maids do Dead-men's fingers call them...

Millais, in his picture of Ophelia, assumes that Shakespeare meant the Purple Loosestrife: but the Loosestrife was never called Dead-men's fingers, nor, for that matter, by any "grosser name". Dead-men's fingers, in fact [...] is [...] loosely used for Orchis mascula, one of the round-tubered species, all of which were given "grosser names", not only by liberal shepherds, but by the early herbalists; the reason being that the twin tubers suggested a pair of testicles. (69-70)

I do not know which pollinated which, but I suspect the process was probably two-way.

\section{The functions of hybridisation}

I would now like to look at the functions of hybridisation. First, within the form of autobiographical narrative, botany provides a means of mapping a personal territory, what Anthony Powell calls "Brooke's own magical personal kingdom". ${ }^{13}$ This I consider to be done through the following underlying analogy: just as what matters to the protagonist/narrator is to find the orchids in their natural habitat-a preoccupation which mirrors Brooke's own ecological approach in The Wild Orchids of Britain- ${ }^{14}$ so the self constructed by the narrative is defined, not primarily along historical lines but ecologically, i.e. in relation to places which-though real-have taken on a mythical status mostly by virtue of their harbouring rare orchids discovered there by the protagonist. The ecological self delineated by The Military Orchid may be seen as a variation on Frédéric Regard's notion of "geographical" self". ${ }^{15}$ The orchids, especially those resembling Orchis militaris, provide a powerful sensory link between the childhood world referred to as "The Land of Lost Content" and a period of adulthood, in Italy during the Second World War, when for a while, the protagonist inhabited another magical territory "The Land of 
Heart's Desire". The names of both territories are quotations: the first one from Poem XL in Housman's A Shropshire Lad, 1896; the second, the title of a short play by W.B. Yeats, 1894. The allegorical names of those lands of botanical happiness further reinforce the link between the child and the adult protagonist by echoing each other in their near identical structure, and their shared metaphorical designation of mental/emotional territories: the rhetorical figure here conveys the complete synthesis between place and self, experienced acutely in nostalgic retrospect.

Both allegorical territories are fused in the title of the last section, "The High Mountains of Clova", a place name mentioned in one of the floras read in childhood by the protagonist, which, though referring in fact to a Scottish glen, never lost its mystery and remained for the narrator the name of a magical place, a fitting appellation for the adult dreamland of Italy.

The combination of autobiography and botany thus provides-in spite of the failure of the quest-the means of recapturing the feeling of happiness connecting the "I" through his past and present sensory perceptions, to the botanical finds and their habitats.

Chapter III of part II reveals another function performed by hybridisation. There, the narrator devotes the whole chapter to examining botanical references in literary works, in English poetry mostly, but also in Shakespeare and Proust. Fragments quoted are subjected to critical scrutiny through the prism of the narrator's botanical knowledge and a hierarchy is established on the basis of botanical accuracy. While the narrator initially presents this pedantic clinging to precision humorously, at his own expense ${ }^{16}$, he observes, more seriously, that "ecologically correct [references to flowers in poetry] for a botanist enhance the poem's effect" (68) and further on, expresses genuine irritation at prose-writers' botanical levity:

Even the most self-consciously rural of novelists seem incapable of being factually accurate about flowers; what makes matters worse is their pretentiousness, their air of omniscience. No novelist would write so cocksurely about numismatics, for instance, or toxicology, without checking his statements; yet anyone can write nonsense about flowers and get away with it. (9)

Two exceptions are D.H. Lawrence and, naturally, Proust, whose specialist knowledge of insect fertilisation of orchids, displayed in the Jupien-Charlus scene of "Sodome et Gomorrhe I", is deemed "almost too technical" by the narrator (69). The narrator's remarks raise interesting questions about the reading of non-referential texts which make use of referential material, and may also call attention to the importance of literal meaning. ${ }^{17}$ His own response as a reader challenges Dorrit Cohn's observation that only referential narratives "are subject to judgments of truth and falsity. Narratives of the second kind, which include novels, short stories, ballads and epics, are immune to such judgments" (15). Obviously, Brooke's narrator had not read Dorrit Cohn and felt free to apply his own exacting botanical criteria to fiction and poetry.

The chapter in which literary criticism is thus filtered by botany immediately precedes the passage already mentioned which picks up the autobiographical narrative thread again in the form of criticism of the protagonist's adolescent novelistic production. The contiguity of the two passages and the similarity of their theme draw attention to Brooke's own answer to the difficulties he had encountered in his previous attempts at novel writing, the answer being precisely the hybrid text of The Military Orchid. Hybridism could have been suggested by the peculiar ambiguous aspect of the orchids themselves, a characteristic stressed both in The Wild Orchids of Britain and The Military Orchid. As already 
noted, the botanical monograph and the novel fed on each other, offering a new perspective on the role of orchids in literature, stemming in this case not from literary precedents but from the confrontation between specialist literature on orchids, plates included, and uncompromising observation of the same plants by the protagonist/ narrator. The question of truth is therefore relevant to The Military Orchid but only concerns the botanical "truth" which is central both to the theme and method of the narrative.

\section{Reading The Military Orchid}

There is, as I have tried to show, no special difficulty in reading The Military Orchid as a novel rather than as straightforward autobiography. In this respect, Dorrit Cohn's argument about borderline cases holds. Philippe Gasparini's position which centres on the ambiguous identity of the protagonist/narrator and leads him to envisage a double simultaneous reception of such texts as fiction and autobiography does not comfortably fit with the experience of reading The Military Orchid. This could be due to a narrative and syntactical decentering of the self and to the prominent place given to the orchids. Whatever autobiographical material may be used in The Military Orchid, it is refined and stylised through the filter of botany. If a double reception is in order in this case, it would be one combining a reading of the work as fiction and as botany, hence my use of Dorrit Cohn's three-level model.

This, however, raises the problem of the reader's knowledge, or at least, awareness, of botanical facts. My own first readings of The Military Orchid, undertaken in complete ignorance of the botanical references (for all I knew, the documentation quoted by the narrator might have been invented), seem to me in retrospect much less rewarding than those carried out after I had read The Wild Orchids of Britain. This is not to say that the novel should not be read for its own sake. Anyway, copies of The Wild Orchids of Britain being almost as rare as specimens of Orchis militaris, comparative reading of the two works remains difficult to effect in practice. I only wished to suggest ways in which our response to a generically hybrid text may be affected by its context, "hors-texte"-to borrow the French expression for "plates"-intertext, and, in this particular case, by what could, paradoxically, be called an hypotext-in-progress, if we consider that The Military Orchid grew out of the rich soil of the yet-uncompleted monograph rather than the reverse. 


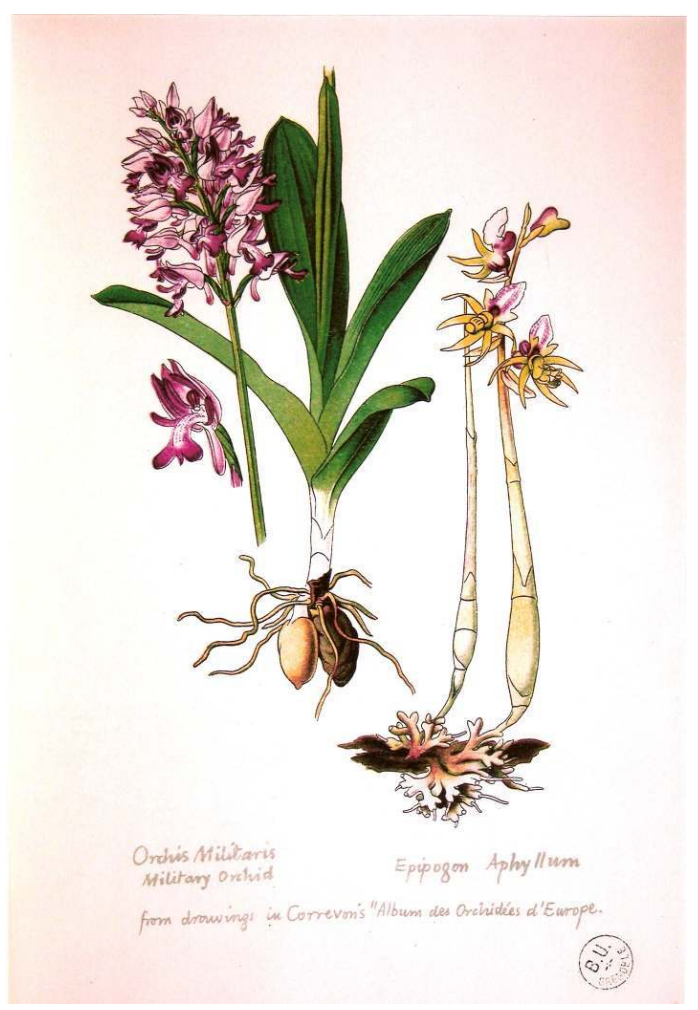

Orchis Militaris (the Military Orchid, from Correvon's Album des Orchidées d'Europe), The Wild Orchids of Britain, plate 26

\section{BIBLIOGRAPHIE}

Brooke, Jocelyn. The Military Orchid and Other Novels (The Military Orchid, 1948; A Mine of Serpents, 1949; The Goose Cathedral, 1950). London: Penguin Books, 2002. (Preface by Jonathan Hunt; introduction by Anthony Powell, 1981)

Brooke, Jocelyn. The Wild Orchids of Britain. London: The Bodley Head, 1950. (Drawings from the living plants by Gavin Bone. Additional drawings by Muirhead and Stephen Bone).

Brooke, Jocelyn. "The Orchid”. Unpublished poem, held by the Harry Ransom Humanities Research Center at the University of Texas at Austin, 1942.

Brooke, Jocelyn. Ronald Firbank. London: Arthur Barker, 1951.

Brooke, Jocelyn. "The Wrong Side of the Blanket: a Letter to a Nephew". The London Magazine, vol. 2, 1955, 47-51.

Cohn, Dorrit. The Distinction of Fiction. Baltimore: The Johns Hopkins UP, 1999.

Furbank, P.N. “Flower Power”. The London Review of Books 25.9 (8 May 2003).

Garrard, Greg. Ecocriticism. Abingdon: Routledge, 2004.

Gasparini, Philippe. Est-il je ? : roman autobiographique et auto-fiction. Paris: Éditions du Seuil, 2004. 
Regard, Frédéric (ed.). Mapping the Self: Space, Identity, Discourse in British Auto/Biography. SaintÉtienne : Publications de l'Université de Saint-Etienne, 2003.

\section{NOTES}

1. All three republished in one volume: Jocelyn Brooke, The Military Orchid and Other Novels, London: Penguin Books, 2002. Preface by Jonathan Hunt; introduction by Anthony Powell (reprint of his 1981 introduction).

2. Dorrit Cohn, The Distinction of Fiction, Baltimore: The John Hopkins UP, 1999, chapter 7: Signposts of Fictionality: A Narratological Perspective.

3. My approach is essentially narratological. If, at times, the botanical context and intertext of The Military Orchid bring me to the marches of ecocriticism, this is purely accidental. In fact, I was, at the time of writing, wholly ignorant of the existence of ecocriticism which was brought to my knowledge by Jean-Jacques Lecercle. My main interest lies in the production and reception of a particular kind of hybrid text, not in the exploration of the cultural/ideological implications of Brooke's literary representation and use of the botanical environment. I suppose, however, that what my own approach has in common with ecocriticism is the recognition that the text bears a relation to an external reality, in the case of The Military Orchid, a botanical reality, itself culturally constructed as is made clear by the novel.

4. "Conscience, however, triumphed in the end, and I had to admit that Mr Bundock's Orchid was not the Military but the Great Brown-Winged. Edward Step, after all, could hardly have invented Orchis purpurea out of sheer malice. No, the Military Orchid, alas! was still unfound. And still isat least by me, and, I imagine, for the last forty years, by anybody else. For Orchis militaris is one of several British plants which have mysteriously become extinct, or very nearly so" (22).

5. In his essay on Ronald Firbank, Brooke observes: "The most one can do is to disinter him like some elusive orchid, from the jungle of half-forgotten 'fiction' and restore him to the light of day [...] one feels he will not object to the orchidaceous simile; for did he not himself bestow upon an (alas! fictitious) orchid the honour of his own name-'Ronald Firbank, a dingy lilac blossom of rarity untold"'. Jocelyn Brooke, Ronald Firbank, London: Arthur Barker, 1951, 10. The quotation is from Ronald Firbank's Prancing Nigger, first published in 1924, reissued in Ronald Firbank, Five Novels, New York: New Directions Books, 1981, 133.

6. Philippe Gasparini, Est-il je? : roman autobiographique et auto-fiction, Paris: Éditions du Seuil, 2004, 14

7. Jocelyn Brooke, "The Wrong Side of the Blanket: a Letter to a Nephew", The London Magazine, vol. 2, 1955: 49.

8. Wormseed was made of the dried heads of various plants used to cure people of parasitic worms. Green mummy, or mummia, was a medicinal preparation supposedly made from Egyptian mummies.

9. In the closing paragraphs of his review of The Military Orchid, P.N. Furbank insists that this was true of Brooke himself: "You might [...] say that botany was the centre of his moral life. For it was a perennial temptation to him to declare that a plant he had found was the military orchid, for which he had so long been searching. He could easily prove it to be so from the best authorities; it was only that, if he searched his heart, he would know that it wasn't. This was a point of honour, and he observed it very faithfully". P.N. Furbank, "Flower Power", The London Review of Books 25.9 (8 May 2003).

10. "[...] there was said to be a subspecies, 0 . simia, the Monkey Orchid, "with narrower divisions of the crimson lip, [...]'. But if Mr Bundock's orchid was not the Military, still less could it be the Monkey; its lip was not crimson, but, on the contrary, pale rose-coloured or nearly white, and 
spotted with purple. Moreover, the sepals and petals were striped and stippled with dark purplish-brown, which fitted with Step's description of Orchis purpurea" (21).

11. Of Gavin Bone's plates for The Wild Orchids of Britain, Brooke said: "his drawings should be judged as works of art, rather than as text-book diagrams. In certain cases, admittedly, he has sacrificed absolute precision of detail to his vision of the plant as a whole; but it seems to me better for an artist to depict the living plant as he sees it, than to strain after a 'scientific' accuracy which (as so many floras bear witness) is apt, by producing a flat and lifeless effect, to defeat its own end". Jocelyn Brooke, The Wild Orchids of Britain, London: The Bodley Head, 1950, 8.

12. The translation is Dorrit Cohn's. The original is found on page 131 of Michel de Certeau, L'Écriture de l'histoire, Paris : Gallimard, 1978.

13. Anthony Powell, introduction to The Military Orchid and Other Novels, 12. Originally published as the introduction to The Orchid Trilogy, simultaneously by Secker and Warburg and Penguin Books, 1981.

14. "To myself the ecology of the plant life-that is, the study of plants in relation to their habitats-has always seemed one of the most attractive and rewarding aspects of botany. Apart from its purely scientific interest, the subject possesses a certain element of poetry: as a quoted line of verse will suddenly evoke by association a complete poem, so a specimen of any given plant will call up not only all the flowers associated with its particular habitat, but the whole 'feeling' and atmosphere of the place itself' (Wild Orchids, 22).

15. In his essay, “Topologies of the Self: Space and Life-Writing”, Frédéric Regard suggests that "when it comes to self-writing, the question is not so much 'who am I?' as 'where am I?' [...] Far from being a writing tradition folded in on the interior self can autobiography not be regarded as a 'journey' the author makes-in other words, an experience of relativity and fluidity, of rupture with the laws of fixity?" Frédéric Regard (ed.), Mapping the Self: Space, Identity, Discourse in British Auto/Biography, Saint-Étienne : Publications de l'Université de Saint-Etienne, 2003, 16, 18.

16. "In my readings of poetry, I was apt to be rather uncritical; but in one respect, I outdid the most academic of textual critics in my pedantry. Inaccurate references to plants were liable to provoke me into a positively Housmanly cantankerousness" (67).

17. In his preface to the new Penguin edition of The Military Orchid, Jonathan Hunt emphasizes metaphorical interpretations: "The Military Orchid and the other orchids mentioned in the text are one of the devices whereby Brooke alludes to what cannot be directly stated, but is frequently present in the three books: 'the love that dare not speak its name"' (xi). Such interpretations are encouraged by the narrator's own comment on Orchis militaris as incarnating the masculine virtues he lacked as a child, by literary precedent, by the obvious phallic and testicular symbolism of the plants, and by Brooke's unpublished poem, "The Orchid", in which his love for a Seaforth Highlander fuses with his quest for a rare orchid into: "A complete and compelling synthesis of the displaced quest and the tangential image" (Jocelyn Brooke, "The Orchid", 1942, unpublished poem held at the Harry Ransom Humanities Research Center, University of Texas at Austin). Yet, this should not obscure the fact that Brooke's and his narrator's love for orchids was a passion in its own right-as P.N. Furbank observes in the already quoted review-and, anyway, predated homosexual desire. My argument throughout has been that the botanical quest, whatever its metaphorical or coded meanings, should also be taken literally. Besides, it could be argued that Brooke's homosexual desire was, at least temporarily, fulfilled, the Seaforth Highlander, complete with kilt and sporran, found and enjoyed, whereas the Military Orchid forever eluded him. 
INDEX

oeuvrecitee Military Orchid (The) 